\title{
DIGITAL TRANSFORMATION AND ITS INFLUENCE ON GDP
}

\author{
Ljubiša Mićić \\ University of Banja Luka, Faculty of Economics, Bosnia and Herzegovina
}

date of paper receipt:

22.11.2017.

Review paper date of sending to review:

30.11.2017. date of review receipt:

04.12.2017.

\section{SUMMARY}

Digital transformation as integration of digital technology into business results in fundamental changes of way world does business, communicate and develops on national and international level. There is increase of high-tech public spending which is connected with increase of need for high-tech as well as importance and benefits that it brings to development of economy. This so called digital or high-tech sector is one of the strategic sectors in the leading world economies, starting from the US and the European Union. EU recognized it in strategic document "Europe 2020" which sees this sector as key factor in smart growth based on tech knowledge and innovation. Europe, especially western and northern Europe, is trying to keep its competitiveness in global tech arena with USA and fast developing countries such as China and India as well as Asian tech giants such are Japan, South Korea and Singapore.

There is increase of European countries investment in digital transformation through private and public ICT sector development which usually has positive impact on economic growth as well as key indicators such are GDP, productivity and employment.

This paper provides basic review of digital transformation and high-tech sector in Europe as well as comparison between EU and Western Balkan countries. Additionally, there is analysis of influence of ICT spending on GDP growth. Paper could serve as basic for further research in area of influence of tech investment on key macroeconomics indicators.

Keywords: digital transformation, ICT spending, GDP

\section{INTRODUCTION}

Digital transformation as a new and modern term in business and technological literature is usually defined as integration of digital technology into business that results in, sometimes fundamental, changes in business operation and delivery of value to customers. It is affecting not just operational work but also has influence on working culture, human relations and speed of change, on microeconomic as well as macroeconomics level. World is witnessing growth challenges and constant political shocks which sometimes cause hard times for countries' government in dealing with everyday issues as well as development problems. That is forcing countries to look for policies that will stimulate growth and create new jobs - make their economies stronger. Information and 
Communications Technologies (ICT further in this paper) is without doubt significant sector in job creation and economy development. However, there is still a certain level of doubt if ICT spending (government as well as private capital spending) has significant or any influence of GDP growth. This doubt is even more important for developing countries in regions with high potential. South East Europe is definitely one of those high potential regions but ICT spending is not on the level of European Union (EU further in this paper) and especially Western Europe and USA level.

ICT is sometimes misinterpreted and mixed with term IT (Information Technology). IT is just one, maybe more important, part of ICT. Second is Telecommunications. ICT is consisted of set of different product and service technologies as well as telecommunication technologies and functionalities. It is not just one of the most important innovation "creators" but also a cause of cultural, economic, political and educational changes. OECD defines it as a "combination of manufacturing and service industries, whose products electronically capture, transmit or display data and information. The production (goods and services) of a candidate industry must primarily be intended to fulfill or enable the function of information processing and communication by electronic means, including transmission and display" (OECD, 2009). For the purposes of this paper, the 2007 OECD ICT sector definition (ISIC Rev. 4) will be used. OECD defines different categories of ICT products: (1) Computers and peripheral equipment; (2) Communication equipment; (3) Consumer electronic equipment; (4) Miscellaneous ICT components and goods; (5) Manufacturing services for ICT equipment; (6) Business and productivity software and licensing services; (7) Information technology consultancy and services; (8) Telecommunications services; (9) Leasing or rental services for ICT equipment and (10) Other ICT services (OECD, 2002). Therefore, investment in ICT should be considered not just as private sector investment but also a public spending in ICT sector and having in mind OECD product categories it is increasingly important sector.

Elena Kvochko, manager of Information Technology Industry at World Economic Forum has identified five common economic effects of ICT (Kvochko, 2013):

Direct job creation

Contribution to GDP growth

Emergence of new services and industries

Workforce transformation

Business innovation

As stated, World Economic Forum has identified ICT sector as one of the sectors that contribute GDP growth. Same article suggest that ICT sector, in the US alone, is expected to aggregate growth of $22 \%$ in number of jobs up to 2020 , which is more than significant number, and it goes almost up to 760000 new jobs. In Australia, the case is quite similar and it goes around 25000 of new jobs annually created in this sector. Additionally, it will have influence on GDP growth from $1.4 \%$ in emerging markets up to 2.5 in China (Kvochko, 2013).

\section{EUROPEAN TECH SECTOR}

Based on Atomico report „The State of European Tech 2016: the future is being invented in Europe“, tech is changing economy in general and sifting not just focus on ICT investment but also on connection between ICT and other industries (ATOMICO, 2016). This report states that Europe tech industry has several characteristics. Since 2011 the number of tech-based startups which are founded in Europe has grown more than three times and just in 2015 tech investment was 2.3bn USD. Europe is becoming recognized by its tech hubs such are London, Berlin or Stockholm. Additional are rising and one of those is without doubt Munich, Zurich, Lisbon and Copenhagen. However, mentioned report does not mention any of East-European cities and definitely none of Southeast-European tech capitals. Furthermore, report states that existing business are investing in 
their tech companies and sometimes even acquiring those.

European tech market is quite divided between west and north on one side and south and especially east on another side. Based on European tech funding report 2015 more than 50\% of all founding rounds raised by European tech companies happened in just two countries: UK and Germany and three the most active investors in European technology companies were, two from Germany (Gründerfonds and Index Ventures) and one from Nordics' Northzone VC (Wauters, 2016). However, European technology startups raised approximately 12 billion euros in 2015 with the most startups in fintech and e-commerce verticals. George Whiteread from Octopus Ventures predicts that European tech market, especially tech startups will continue to record growth in 2016. In his article "The European investment and technology industry trends in 2016" he notices that sectors as fintech will have continuation of growth and that West Europe, leaded by UK, Germany, Nordics as well as rising France will continue to dominate European tech market supported by adequate public policies that supports this industry (Whitehead, 2016). There is significant data that proves that tech sector in Europe is very important and considered as one of the key industries for European governments. 


\section{HIGH-TECH STATISTICS IN EUROPE - ECONOMIC DATA}

High-tech industry is becoming more and more important for global race and European Union as well as other European developed countries (such are Switzerland and Norway) have recognized this industry as potential economic competitiveness factor. EU has recognized this sector as driver for economic growth and productivity and sector that provides high value-added and well-paid employment which has high value for European governments.

Based on Eurostat statistics from 2014 there are almost 46000 enterprises in high tech manufacturing and even more in high-tech knowledge-intensive service sector (Eurostat, 2014). However even statistics prove that there is division between strongly developed West and less developed East and new EU countries. Four countries, Germany, UK, Italy and Poland together have more that $53 \%$ of the high-tech manufactures in EU-28 and in high-tech, knowledge-intensive service sector difference is even higher: UK has 180257 enterprises; France 141647 and Germany 112570. As obvious, Poland is exemption but also a model for East and "new EU" countries and represents good example for other east European countries to follow in their tech-developing strategies and policies. Turnover is proven higher in high-tech knowledge-intensive service sector than in high tech manufacturing sector however, there are some exceptions (Eurostat, 2014). Germany's high-tech manufacturing turnover was in 2014121 billion euros, followed by France ( 68 billion euros) and Italy (44 billion euros). Knowledge-intensive services are proved to generate a value of production at least 300\% higher than high-tech manufacturing in the several countries such are UK, Portugal, Lithuania, Greece, Spain and Romania. Once more, rich west countries such are UK, Germany, France and Italy are proved leaders in this sector, which is obvious in table with full data from Eurostat statistics.

Table 1 Economic statistics on high-tech sectors in 2014 in EU and some EFTA countries Source: (Eurostat, 2014)

\begin{tabular}{|c|c|c|c|c|c|c|c|c|c|c|c|c|c|c|c|c|c|}
\hline & \multicolumn{9}{|c|}{ Kigh-tech manufacturing } & \multicolumn{8}{|c|}{ High-tech knowledge intensive services } \\
\hline & \multicolumn{2}{|c|}{$\begin{array}{l}\text { Number of } \\
\text { enterprises }\end{array}$} & \multicolumn{2}{|l|}{$\begin{array}{l}\text { Turnover } \\
\text { (EUR } \\
\text { million) }\end{array}$} & \multicolumn{2}{|c|}{$\begin{array}{l}\text { Production } \\
\text { value } \\
\text { (EUR } \\
\text { million) }\end{array}$} & $\begin{array}{l}\text { Value } \\
\text { added } \\
\text { (EUR } \\
\text { million) }\end{array}$ & \multicolumn{2}{|r|}{$\begin{array}{l}\text { Gross } \\
\text { investment } \\
\text { in tangible } \\
\text { goods } \\
\text { (EUR million) }\end{array}$} & $\begin{array}{l}\text { Number of } \\
\text { enterprises }\end{array}$ & \multicolumn{2}{|l|}{$\begin{array}{l}\text { Turnover } \\
\text { (EUR } \\
\text { million) }\end{array}$} & \multicolumn{2}{|c|}{$\begin{array}{l}\text { Production } \\
\text { value } \\
\text { (EUR } \\
\text { million) }\end{array}$} & \multirow[t]{2}{*}{$\begin{array}{c}\text { Value } \\
\text { added } \\
\text { (EUR } \\
\text { million) }\end{array}$} & \multicolumn{2}{|c|}{$\begin{array}{l}\text { Gross } \\
\text { investment } \\
\text { in tangible } \\
\text { goods } \\
\text { (EUR million) }\end{array}$} \\
\hline EU-28 & 46.097 & $p$ & 524.520 & $p$ & 470.349 & $p$ & : & & 18.107 & s & : & & $:$ & & & $:$ & \\
\hline BE & 566 & & 17.425 & & 18.553 & & 7.527 & & 830 & 28.617 & 33.549 & & 33.931 & & 14.709 & 3.234 & \\
\hline BG & 414 & & : & c & : & c & : & c & : & 9.919 & 3.734 & & 3.571 & & 1.863 & 389 & \\
\hline$C Z$ & 3339 & & 12.065 & & 11.695 & & 1.735 & & 335 & 31.561 & 11.633 & & 11.127 & & 5.122 & 601 & \\
\hline DK & 648 & & 16.018 & & 15.787 & & 7.580 & & 600 & 15.115 & 21.339 & & 18.406 & & 9.836 & 991 & \\
\hline DE & 8.827 & & 121.114 & & 110.528 & & 42.906 & & 4.281 & 112.570 & 221.094 & & 180.334 & & 109.543 & 12.193 & \\
\hline $\mathrm{EE}$ & 128 & & 1.871 & & 1.836 & & 170 & & 30 & 3.875 & 1.583 & & 1.473 & & 711 & 108 & \\
\hline E & : & & : & & : & & : & & : & : & : & & : & & : & : & \\
\hline EL & 295 & & 1.543 & & 1.378 & & 552 & & 122 & 12.106 & 7.422 & & 5.555 & & 3.019 & 545 & \\
\hline ES & 2668 & & 17.193 & & 16.234 & & 6.230 & & $\$ 98$ & 50.116 & 68.707 & & $\$ 3.443$ & & 30.047 & 2.497 & \\
\hline FR & 3.178 & & 68.467 & & 60.668 & & 19.614 & & 1.869 & 141.647 & 156.964 & & 160.988 & & 69.412 & 8.957 & \\
\hline HR & $\$ 44$ & & 1.126 & & 1.051 & & 447 & & 94 & 5.383 & 3.069 & & 2.919 & & 1.452 & 199 & \\
\hline$\pi$ & 5.453 & & 44.247 & & 42.884 & & 13.962 & & 1.578 & 100.384 & 96.813 & & 99.232 & & 44.370 & 4.864 & \\
\hline $\mathrm{Cr}$ & : & c & : & c & : & c & : & c & : & 866 & 1.076 & & 1.030 & & 560 & 151 & \\
\hline LV & 171 & & : & c & : & c & : & c & : & 5.294 & 1.520 & & 1.424 & & 696 & 122 & \\
\hline LT & 168 & & 390 & & 358 & & 138 & & 21 & 4.803 & 1.606 & & 1.410 & & 765 & 130 & \\
\hline LU & 10 & & : & c & : & c & : & c & : & 2.009 & : & c & : & c & : & c & c \\
\hline $\mathrm{HU}$ & 1.525 & & 13.674 & & 12.036 & & 2.784 & & 438 & 35.154 & 10.055 & & 7.432 & & 4.027 & 707 & \\
\hline MT & 36 & & : & c & : & c & : & c & : & : & : & c & : & c & : & c & c \\
\hline NL. & 1.813 & & 38.930 & & 33.772 & & 5.023 & & : & 84.213 & 55.054 & & $\$ 1.622$ & & 25.412 & 3.519 & \\
\hline AT & 688 & & 9.431 & & 8.818 & & 3.902 & & 582 & 18.321 & 19.847 & & 14.468 & & 8.887 & 1.038 & \\
\hline PL & 3.461 & & 12.857 & & 11.700 & & 2.387 & & 390 & 73.280 & 25.283 & & 22.894 & & 11.129 & 1.618 & \\
\hline PT & 468 & & 2.740 & & 2.338 & & 711 & & 116 & 14.726 & 10.382 & & 10.101 & & 4.594 & 1.162 & \\
\hline RO & 990 & & 2.596 & & 2.388 & & 748 & & 191 & 17.284 & 8.896 & & 8.637 & & 4.088 & 1.075 & \\
\hline SI & 347 & & 2.450 & & 2.331 & & 981 & & 228 & 8.543 & 2.982 & & 2.657 & & 1.243 & 206 & \\
\hline SK & 796 & & 6.216 & & 5.971 & & 687 & & 123 & 14.084 & 5.244 & & 4.721 & & 2.254 & 428 & \\
\hline F1 & 600 & & 24.491 & & 11.002 & & 2.735 & & 234 & 9.223 & 15.592 & & 15.102 & & 7.382 & 1.299 & \\
\hline SE & ; & c & : & c & : & c & : & c & : & 54.120 & 49.863 & & 40.779 & & 17.451 & 2.215 & \\
\hline UK & 6.504 & & 40.922 & & 37.599 & & 16.608 & & 1.380 & 180.257 & 248.404 & & 237.656 & & 120.333 & 15.021 & \\
\hline NO & 309 & & 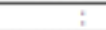 & c & 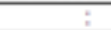 & c & 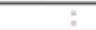 & c & : & 14.043 & 23.175 & & 22.100 & & 10.596 & 1.338 & \\
\hline $\mathrm{CH}$ & 1.664 & & 105.129 & & 110.403 & & 35.102 & & 3.443 & 6.470 & : & c & : & c & : & c & c \\
\hline & $\begin{array}{l}\text { Not avallable } \\
\text { Estimate } \\
\text { Confidential } \\
\text { Provisional }\end{array}$ & & & & & & & & & & & & & & & & \\
\hline
\end{tabular}


The high tech products industry represents $17 \%$ of the value of all exports from EU-28 in 2014, which proves to be extremely important sector. Percentage ranges from $35.3 \%$ share in Malta to just 2.9\% share in Greece. Again, in a trade sector, Germany is again a leading economy of EU and the most important exporter to the rest for the world in 2015, followed by some other also west European countries such are Netherlands, France, UK. However, although Eurostat notices that in 2015 more than $2 / 3$ of the countries recorded increase of their high-tech export from 2014 levels, EU has recorded deficit with imports around 22 billion euros higher than exports which still emphasis importance of further investments in this sector (Eurostat, 2014).

Figure 1 High-tech exports by high-technology group of products, EU-28 and selected countries, 2015, in \%. Source: (Eurostat, 2014)

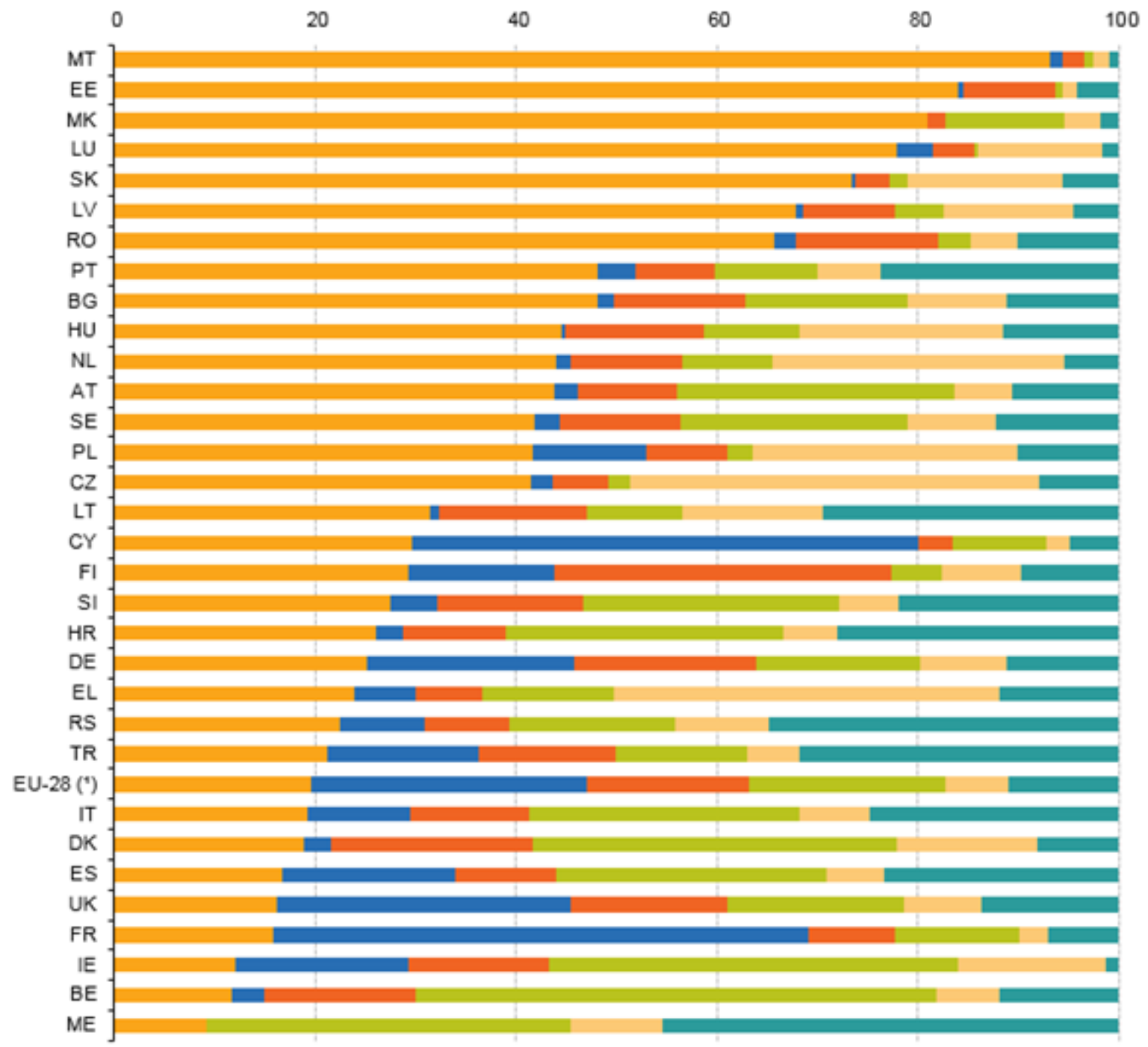

\begin{tabular}{|c|c|}
\hline = Electronic s-telecommunications = Aerospace & $=$ Scientific instruments \\
\hline = Computers-office machines & $=$ Other $\left(^{2}\right)$ \\
\hline
\end{tabular}

(1) Extra-EU trade.

(') Other' includes 'Electrical machinery', 'Chemistry', Non-electrical machinery' and 'Atmament'.

EU has recognized importance of Research and Development (R\&D in further text) for tech sector. Based on Eurostat R\&D spending has increased by an average of 4\% in year 2015/2014 reaching 182 billion in 2014. Again, western countries such are Germany, France and UK accounted for more than half of total R\&D spending in 2014 with especially noticeable Germany's 11.5 billion Euros or $20 \%$ of its total R\&D spending (Eurostat, 2014). UK was leading nation in R\&D spending in 2014 with 14 billion euros. 
Figure 2 Average annual growth rate of R\&D expenditure in business enterprises, 2005-2014 (Eurostat, 2015)

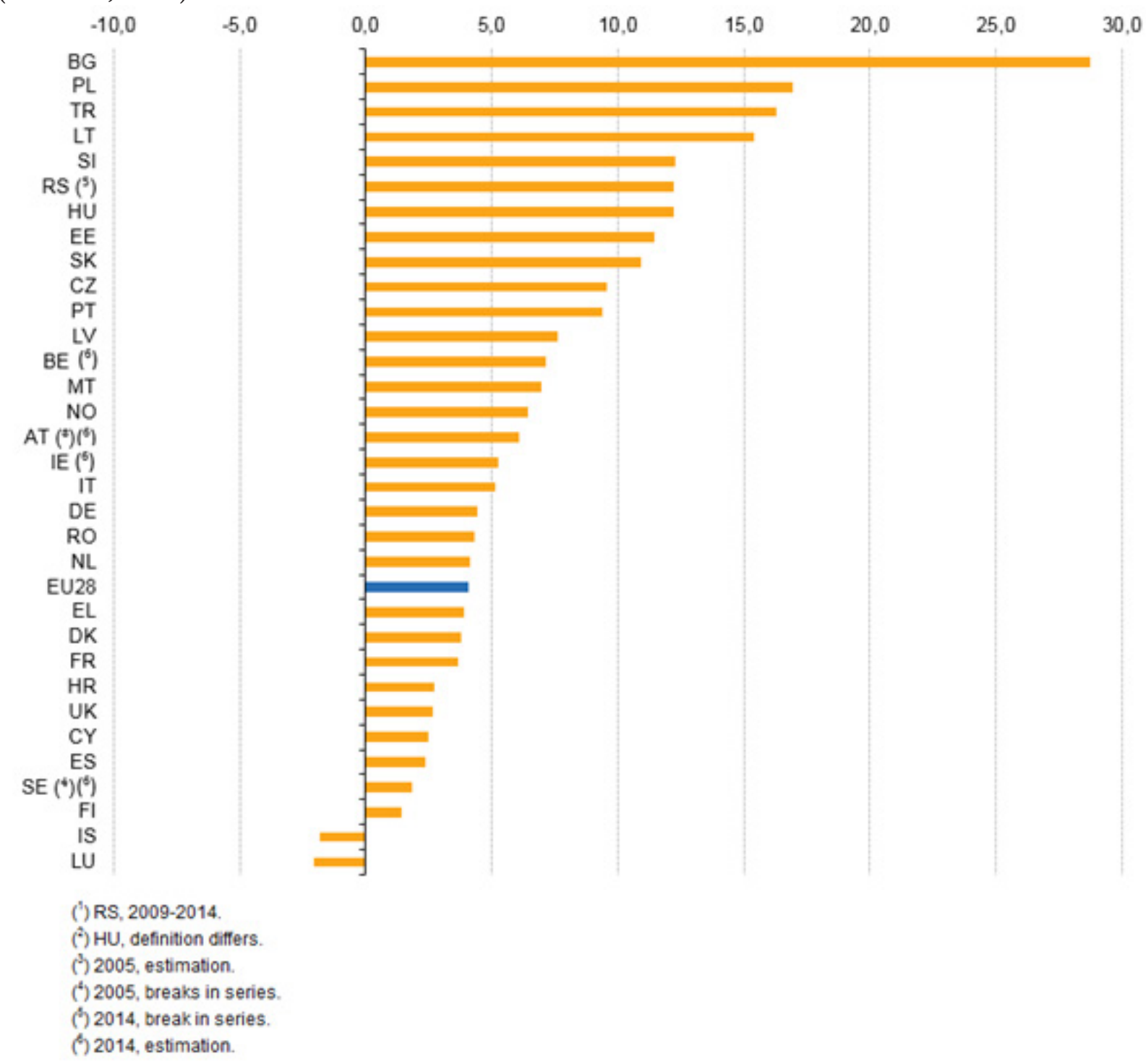

It is also interesting to analyze venture capital investments (VCI in further text) in EU. Based on Eurostat data in 2015 VCI has reached level of around 45 billion of euros per year (Eurostat, 2015). However, VCI represents less than 1\% of GDP in each country except UK in 2007, 2008, 2010 and 2011 and in Luxembourg in 2008. However, level of 45 billion euros is significantly smaller than 70nillion in 2007 before the economic crisis. 
Table 2 Total venture capital investment (VCI), in millions of euros. Source: (Eurostat, 2015)

\begin{tabular}{|c|c|c|c|c|c|c|c|c|c|}
\hline & 2007 & 2008 & 2009 & 2010 & 2011 & 2012 & 2013 & 2014 & 2015 \\
\hline$E U(1)$ & 70.276 & 51.636 & 22.816 & 40.019 & 44.570 & 35.275 & 36.116 & 38.745 & 44.497 \\
\hline $\mathrm{BE}$ & 1.048 & 636 & 1.018 & 476 & 590 & 522 & 925 & 664 & 722 \\
\hline$B G$ & 39 & 15 & 6 & 5 & 11 & 65 & 2 & 1 & 16 \\
\hline $\mathrm{CZ}$ & 70 & 40 & 61 & 37 & 193 & 17 & 24 & 14 & 13 \\
\hline DK & 1.334 & 512 & 452 & 439 & 421 & 694 & 1.484 & 663 & 1.162 \\
\hline $\mathrm{DE}$ & 8.083 & 7.115 & 2.619 & 4.826 & 4.439 & 5.315 & 6.146 & 5.922 & 5.996 \\
\hline IE & 321 & 75 & 59 & 48 & 65 & 93 & 91 & 138 & 161 \\
\hline EL & 90 & 234 & 39 & 15 & 9 & 0 & 1 & 0 & 0 \\
\hline ES & 2.923 & 1.681 & 959 & 2.480 & 1.974 & 1.475 & 754 & 958 & 1.051 \\
\hline FR & 12.725 & 8.551 & 3.457 & 5.959 & 9.264 & 5.247 & 5.925 & 8.998 & 9.451 \\
\hline IT & 2.839 & 3.400 & 1.385 & 905 & 1.211 & 1.192 & 1.159 & 735 & 1.160 \\
\hline LU & 68 & 425 & 82 & 101 & 240 & 250 & 71 & 67 & 74 \\
\hline $\mathrm{HU}$ & 48 & 34 & 191 & 45 & 78 & 104 & 22 & 101 & 118 \\
\hline NL & 2.843 & 1.763 & 805 & 1.326 & 2.101 & 1.362 & 1.002 & 1.904 & 1.708 \\
\hline AT & 394 & 214 & 140 & 130 & 124 & 155 & 86 & 106 & 109 \\
\hline $\mathrm{PL}$ & 435 & 727 & 482 & 504 & 692 & 541 & 352 & 337 & 802 \\
\hline PT & 206 & 399 & 299 & 203 & 442 & 229 & 273 & 237 & 150 \\
\hline RO & 156 & 123 & 83 & 80 & 48 & 24 & 49 & 41 & 50 \\
\hline $\mathrm{FI}$ & 381 & 487 & 370 & 442 & 437 & 483 & 556 & 566 & 512 \\
\hline SE & 3.010 & 3.330 & 1.337 & 3.135 & 2.166 & 2.022 & 1.557 & 1.616 & 1.722 \\
\hline UK & 34.012 & 22.813 & 9.793 & 19.534 & 21.085 & 16.236 & 16.086 & 16.170 & 20.521 \\
\hline NO & 698 & 770 & 642 & 936 & 706 & 880 & 883 & 1.287 & 1.165 \\
\hline $\mathrm{CH}$ & 970 & 1.084 & 718 & 1.555 & 640 & 662 & 609 & 1.237 & 640 \\
\hline
\end{tabular}

(1) The EU aggregate is calculated based on data available for listed countries.

\section{EU POLICIES IN ORDER TO DEVELOP TECH SECTOR}

EU has developed several policies in order to develop tech sector in Europe and to make it make it less dependent on products and service from US and other global player's economies. In $2010 \mathrm{EU}$ has developed strategic document "Europe 2020", a strategy which sets out a vision of social market economy in Europe in 21st century. It writes about three reinforcing priorities:

smart growth - developing an economy based on knowledge and innovation;

sustainable growth - promoting a more resource-efficient, 'greener' and more competitive economy;

inclusive growth - fostering a high-employment economy, delivering social and geographical cohesion.

Strategy is developed by the European Commission and it has strengthened by seven flagship initiative of which for the tech sector the most important is "smart growth". Additionally, European Commission Communication published "Regional Policy contributing to smart growth in Europe 2020" which highlights regional contribution and funding to innovation in all regions. A main element of this document it to encourage national and regional government in identification of the key resources in order to identify their own best assents and with focus on limited number of priorities that will ensure the most effective use of public funding but also private investment. Additionally, European Council has published a Communication on "Measuring Innovation output: towards a new indicator" which has a main aim to measures the extent to which innovations are able to reach market in reality and in which amount it makes Europe more competitive. The indicator has been using some of Eurostat's science, technology and innovation (so-called STI) statistics and concepts. It all contributes in strategy development as well as measurements of initiatives in The Europe 2020 strategy as strategy for sectors of the future among tech sector plays important role. ICT spending per capita in Europe

One of the key data in understanding tech and especially ICT market in Europe is ICT spending 
per capita. It is data that shows how much money is spent for ICT per capita which is respectful data because it takes to account number of citizen. For example in Europe in 2013 the leading country is UK with 1912 euros per capita spending on ICT which is quite above EU average for the same year (1182 euros). Germany and France are following UK with 1476 and 1413 euros, respectfully. After them, there is Spain with 904 and Italy with 876 euros (Bitkom Research, 2015). But Europe is still losing this battle compared to US market where average is 2468 euros per capita of ICT spending which still makes US as a global leader in tech sector, not just as a manufacturer/ service provider but also as a tech market. Germany as a leading economy is additionally interested for comparison of how this ICT spending per capita is distributed among two parts of ICT. 52\% of this spending is spent on IT and 48 on Telecommunication which is quite similar in other western economies. It is different in emerging and fast growing markets such are China and Brazil where is still significantly more percentage spent on telecommunications: more than $70 \%$ in both countries (Bitkom Research, 2015).

Figure 3 Distrubution of ICT spending per capita on IT and telecomunication in 2014 (Bitkom Research, 2015)

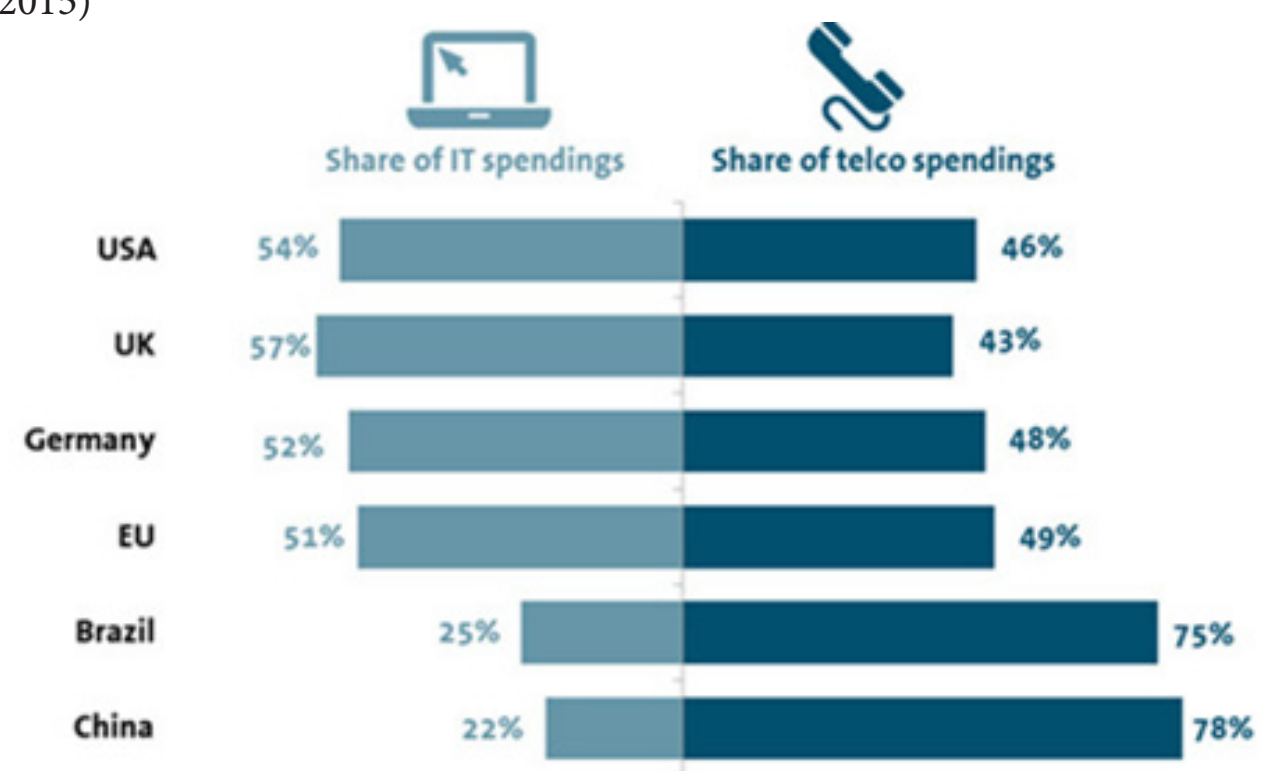

But not just that ICT spending per capita has a growth. It is noticable that general ICT spending has a growth which si promising for this industry. Statista predicts that ICT spending from 2015 to 2020 will continue to grow. In 2015 their research confirmed growth by $2.9 \%$ on worlwide level (Statista, 2015). 
Figure 4 percentage of year on year growth of ICT spending by segments (Statista, 2015)

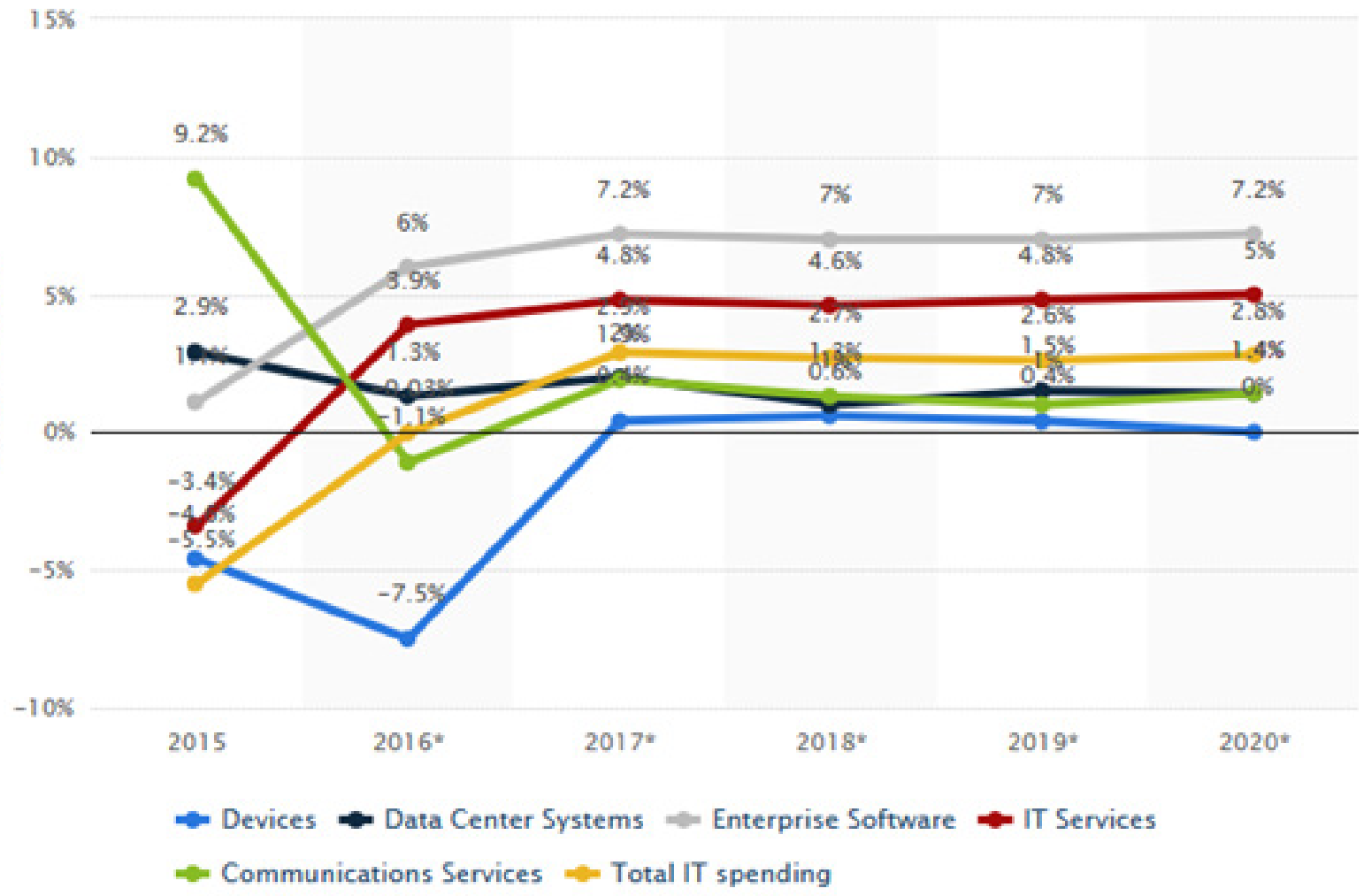

ICT spending and GDP per capita in Europe: correlation between ICT investment and GPD per capita growth

Based on Eurostat statistics and research "ICT in Serbia - At a Glance" Europe is quite divided in technological industry. When we compare two above mentioned parameters it is more than obvious that leading western EU countries, such are Germany, UK and France, are far away from western Balkan countries such are Serbia, Bosnia and Herzegovina, Macedonia and Albania (Matijevic \& Solaja, 2015). Based on so called Technological map of Europe (which compares GDP per capita and ICT spending) it is easy noticeable that there from four possible quadrants there are only two filled with countries: one where countries have high GDP per capita and ICT spending and another one, where are some of the western countries too, which is quadrat of low ICT spending and low GDP per capita (Matijevic \& Solaja, 2015).

Technological map of Europe, comparison of GDP per capita and ICT spending, identifies six tiers (Matijevic \& Solaja, 2015):

Tier 1: UK, Germany and France

Tier 2: Denmark, Sweden, Nederland, Finland, Austria and Belgium

Tier 3: Italy and Spain

Tier 4: Greece, Portugal and Slovenia

Tier 5: Central and Eastern Europe

Tier 6: Baltic and West Balkan Countries

It also takes to account how big IT market is based on the size of the circle: from 1 billion to 70 billion.

Matijevic and Solaja identify some of the key points of this map:

North and west European countries, part of tiers 1 and 2, have high GDP per capita but also a significant ICT investments,

It is different when we look at south Mediterranean countries such are Portugal, Spain, Italy and Greece which have significantly smaller GDP per capita but also significantly smaller ICT spending, All so called "new members" with maybe except of Slovenia are in the third league and difference in ICT investment is really strong. 
Balkans and Baltics are far away from EU average and there is huge need for significant ICT investments in order to catch up with EU average (Matijevic \& Solaja, 2015).

Matijevic even suggests that "The Serbian economy and society will avoid further drop to even deeper crisis if the IT investments from present $<1 \%$ of GDP growth to $2 \%$ of GDP in the period 2011-2015". To jump the EU bandwagon, it is necessary to triple IT investments in Serbia in the same period" (Matijevic \& Solaja, 2015).

Figure 5 Technological map of Europe, comparison of GDP per capita and ICT spending (Matijevic \& Solaja, 2015)

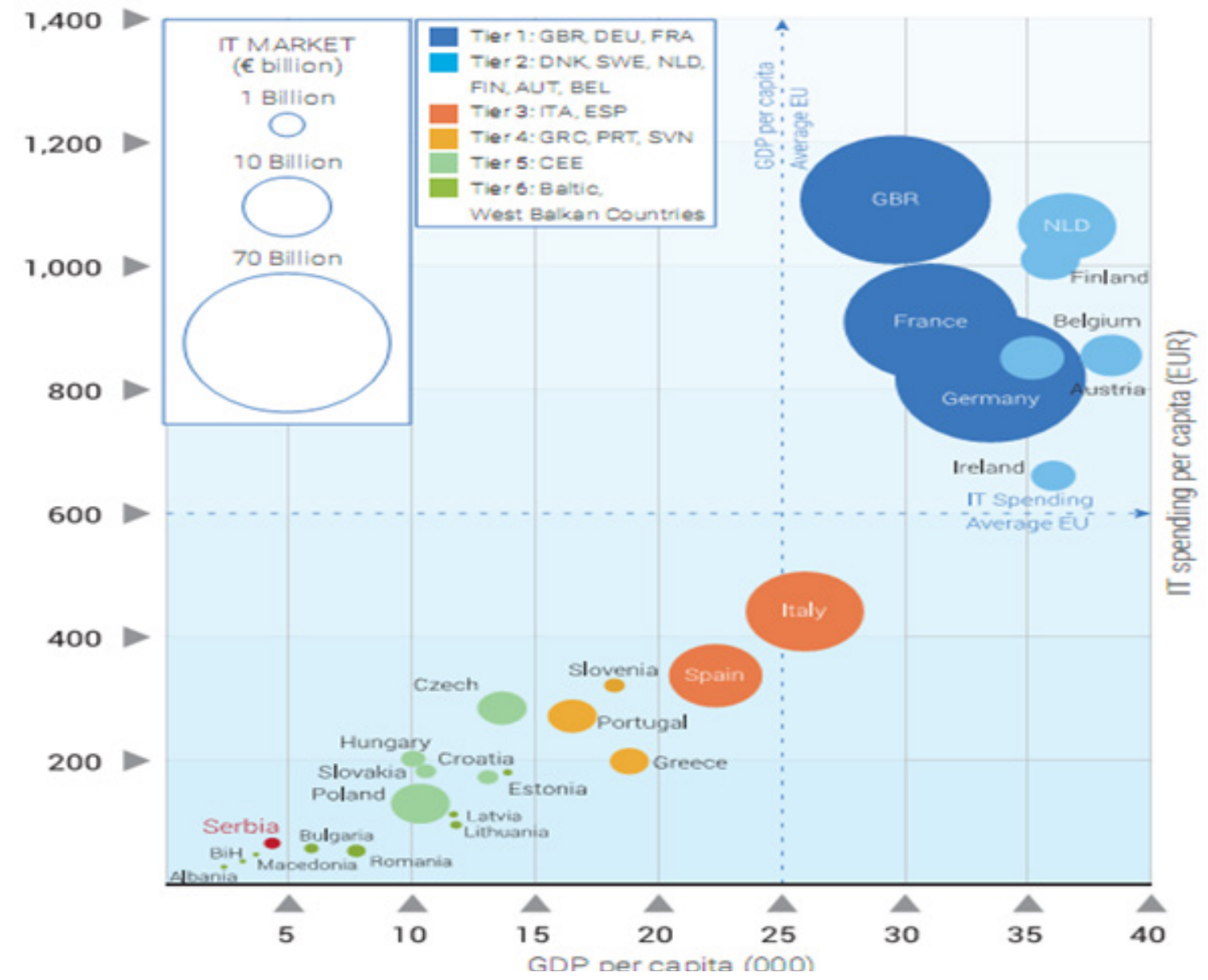

Based on above mentioned technological map it is easy to notice that countries with significantly higher ICT spending are those with greater GDP per capita. There are two possible conclusions for this: they have more need for ICT investment due to greater ICT penetration in business as well as in everyday life, or they want, based on public policies and strategic orientation, to develop their ICT sector and make it more leading sector than it is now. Based on this map it is also notable that there are three groups of countries: rich west and north with higher GDP per capita and higher ICT investment, medium Mediterranean countries and less developed eastern and southeastern countries with strong lag compared to their European neighbors. In the same report it was emphasized for Serbia, which could be almost fully applied to all the other SEE countries, that crucial investment is expected from government spending and investment in order to achieve EU level of IT usage in education, health, public and other sectors. Having in mind that Serbia, as well as other western Balkan countries, is willing to apply for EU membership so therefore, it should has ICT spending on minimum level of EU10 when they joined EU. That minimum is 1 billion of euros (Matijevic \& Solaja, 2015) which is cca 150 euros per capita (when we divide it with number of Serbian population). But based on current data for 2015 which tell us that ICT market is only on level of 413 million of euros it leads us that Serbian market should have a rise of more than $10 \%$ per year in order to be close to desired level before 2023. 
Figure 6 Trends and Potentials - New IT Goal for the Period 2015-2020 in Serbia (Matijevic \& Solaja, 2015)

1,200

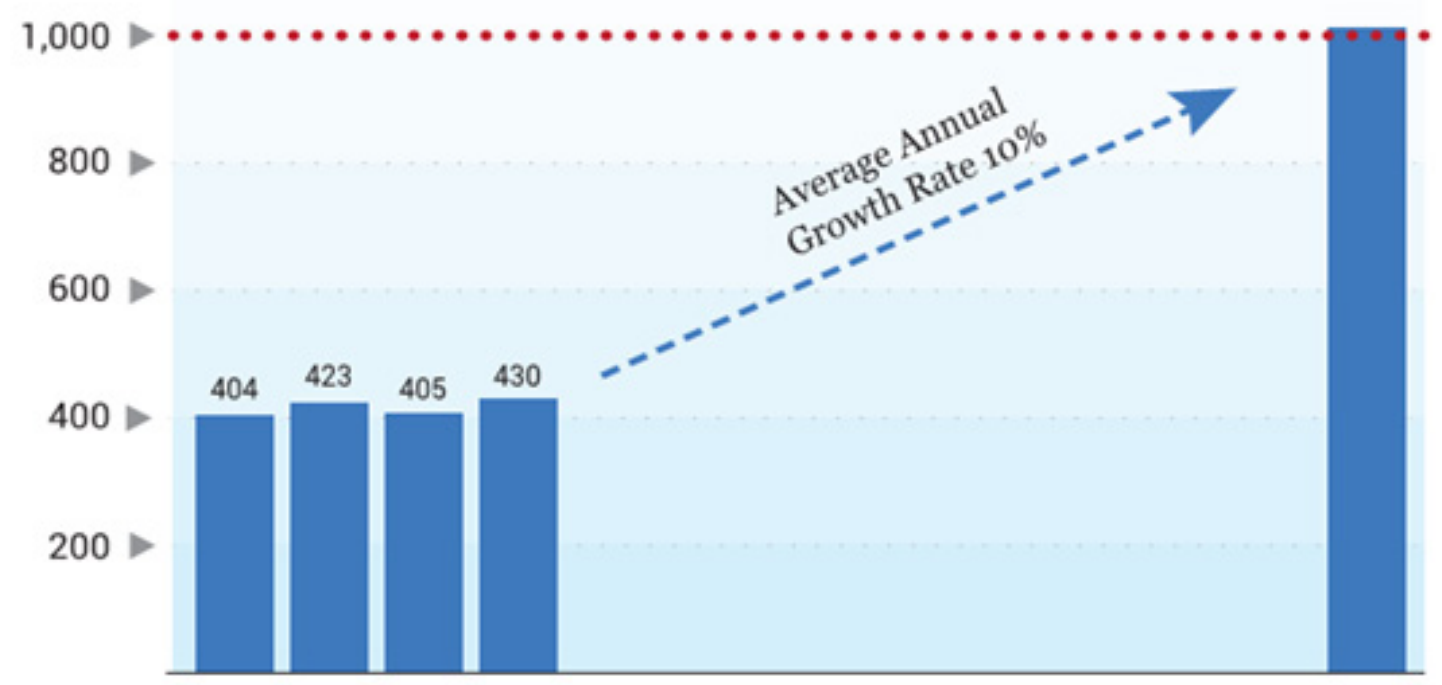

However, same report predicts that in order to achieve that level of EU10 in 2004 (level of 1 billion of ICT spending) it should be government top priority and should be one of the key sector for not just investments but also for a policy and strategy support.

Farhadi and group of authors in paper "Information and Communication Technology Use and Economic Growth" have proved that there is a positive relationship between growth rate of real GDP per capita and ICT use index (as measured by the number of internet users, fixed broadband internet subscribers and the number of mobile subscription per 100 inhabitants) using Generalized Method of Moments (GMM) estimator within the framework of a dynamic panel data approach and applies it to 159 countries over the period 2000 to 2009 (Farhadi, Ismail, \& Fooladi1, 2012). They have also found that the effect of ICT use on economic growth is higher in high income and richer countries rather than other (Farhadi, Ismail, \& Fooladi1, 2012).

Dedrick and group of authors also state that ICT investment should not be consider as pure investment in hardware but also investment in telecommunications as well as related software and services (Dedrick, Gurbaxani, \& Kraemer, 2003).

Different researcher had focus on influence of ICT investment on GDP growth. Jalava and Pohjola have stated that that ICT is one of two the most important factors in US economic growth in the 1990s. Additionally, they prove that ICT boosts growth in Finland from $0.3 \%$ to $0.7 \%$ in 1990 s (Jalava \& Pohjola, 2002).

Schreyer stats that impact of ICT capital to economic growth of some European countries, the United States, Canada, and Japan during 1990-1996 is about 0.17-0.29\% (Schreyer, 2000). Daveri expand mentioned Schreyer's research to additional European and five others countries and proves significantly higher impact of ICT on GDP growth. But both researchers agree it is smaller influence than in the USA (Daveri, 2000). Some authors have doubts regarding influence of ICT investment in less developed or developing countries. Therefore, group of authors suggest that this influence is significantly smaller in developing economies which they suggest is influenced by human capital, knowledge-based structures and small previous IT investment which are prerequisite for productivity of current ICT investment (Dewan \& Kraemer, 2000). Some researchers, for example Kiley, state that impact of ICT on economic growth is even negative due to adjustment cost (Kiley, 1999). He suggests that introduction of new technology is imposing large adjustment costs for the economy and decrease economic growth (Kiley, 1999). However, this statement is considered outdated and cannot be taken seriously based on date when it was concluded. 
Digital economy and influence of the information and communication technologies to economic growth

Digital economy should be one of the key sectors for economic growth and booster for new employment. In one of his papers Mastilo identifies four key impacts of the digital economy on today's global economy: it created a new use-value of products and services, it has a destructive impact which threatens traditional business, it created a new way of communication and it a chance for creation of new jobs (Mastilo, 2017). In the USA it has influenced in creation of 500000 new jobs which could be also a role model and example for economies of the Southeast European countries (Mastilo, 2017). Some authors stated that the increase of the IT production in economic output may increase the overall level of productivity of a country (Albers, 2006). Some research showed that $22 \%$ of the global economy is actually digital economy which proves that countries as well as business and individual should invest more in ICT as a development potential area (Mastilo, 2017). Additionally, same paper quotes Oxford study in 2016 which predicts that the development of the digital economy by 2020 would contribute to the economic growth of $25 \%$ (Mastilo, 2017). However, all this requires further research in order to prove that investment in ICT and digital economy can have significant effect to GDP and economic growth.

\section{CONCLUSION}

Forbes has indentified that change in area of digital transformation is going to happen whether you pursue it or not. Government as well as companies and individual should do all they can in order to gain benefits from it in key economic indicators. Real digital transformation requires financial investments and public spending in order to achieve adequate level on development and to have some positive impact on macroeconomic indicators. Although there are researches, reports and studies that correlate high GDP per capita with high ICT investment and spending there is no adequate study which completely confirms that hypothesis. Based on that, this correlation could be result of other economic processes and public policies. Therefore, there is a reasonable level of doubt that high ICT investment has unreasonable impact on GDP per capita. However, technological map of Europe identifies that those countries with high level of ICT investment are those countries that also have high GDP per capita. Therefore, further increase of ICT investments and development of ICT industry should be one of the key priorities in south-east Europe in order not just to achieve level of EU10 countries in 2004 but also to join group of the countries in central Europe with medium GDP per capita and more developed economies. Further investments in high tech sector can just improve digital transformation and with proper use has positive effects on macroeconomic indicators. 


\section{BIBLIOGRAPHY - RESEARCH SOURCES}

1. Albers, R. M. (2006). From James Watt to Wired Networks: Technology and Productivity in the Long Run in Mas. Growth, Capital and New Technologies.

2. ATOMICO. (2016, January). http://www.atomico.com. Preuzeto sa State of European Tech 2016: http://www.atomico.com/news/the-state-of-european-tech-2016

3. Bitkom Research. (2015). EITO ICT Market Report 2014/15 Update. Bitkom.

4. Daveri, F. (2000). Is Growth an ICT-story in Europe too? IGIER, 168.

5. Dedrick, J., Gurbaxani, V., \& Kraemer, K. (2003). Information technology and economic performance: A critical review of the empirical evidence. ACM Computing Surveys 35, 1-28.

6. Dewan, S., \& Kraemer, K. (2000). Information technology and productivity: Preliminary evidence from country-level data. Management Science 46 (4), 548-562.

7. Eurostat. (2014). Economic statistics on high-tech sectors in 2014. Eurostat.

8. Eurostat. (2015). Economic statistics on high-tech sectors in 2015. Eurostat.

9. Farhadi, M., Ismail, R., \& Fooladi1, M. (2012). Information and Communication Technology Use and Economic Growth. PLOS ONE.

10. Jalava J, P. M. (2002). Economic growth in the new economy: Evidence from advanced economies. Information Economics and Policy 14, 189-210.

11. Jalava, J., \& Pohjola, M. (2002). Economic growth in the new economy: Evidence from advanced economies. Information Economics and Policy 14, 189-210.

12. Kiley, M. (1999). Computers and Growth with Costs of Adjustment: Will the Future Look Like the Past?. . Finance and Economics Discussion Series Paper 1999, str. 36. Preuzeto sa http://www. federalreserve.gov/pubs/feds/1999/index.html

13. Kvochko, E. (2013, April 11). Preuzeto sa World Economic Forum: https://www.weforum.org/ agenda/2013/04/five-ways-technology-can-help-the-economy/

14. Mastilo, Z. (2017). Impact of Digital Growth in Modern Business. Red frame, 3(4), 59-63. doi:10.11114/bms.v3i4.2650

15. Matijevic, M., \& Solaja, M. (2015). ICT in Serbia - At a Glance. Novi Sad: Vojvodina ICT klaster.

16. OECD. (2002). Measuring The Information Economy. OECD: Paris.

17. OECD. (2009). Guide to Measure the Information Society, . Paris: OECD.

18. Schreyer, P. (2000). The Contribution of Information and Communication Technology to Output Growth: A Study of the G7 Countries. OECD Science, Technology and Industry 2000/02.

19. Statista. (2015). https://www.statista.com/. Preuzeto sa https://www.statista.com/: https://www. statista.com/statistics/268940/percent-growth-in-it-spending-worldwide-by-segment/

20. Wauters, R. (2016). European Tech Funding Report 2015. European Tech Funding.

21. Whitehead, G. (2016, January 18). Real Business. Preuzeto sa http://realbusiness.co.uk/tech-andinnovation: http://realbusiness.co.uk/tech-and-innovation/2016/01/18/the-european-investmentand-technology-industry-trends-to-expect-in-2016/ 